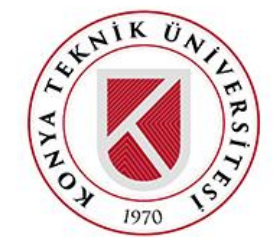

Konya Mühendislik Bilimleri Dergisi, c. 9, s. 3, 836-844, 2021

Konya Journal of Engineering Sciences, v. 9, n. 3, 836-844, 2021

ISSN: 2667-8055 (Elektronik)

DOI: $10.36306 /$ konjes.969989

\title{
DIGITAL TWIN CONCEPT FOR RENEWABLE ENERGY SOURCES
}

\author{
Göksel GÖKKUŞ \\ Nevşehir Hacı Bektaş Veli Üniversitesi, Mühendislik-Mimarlık Fakültesi, Elektrik-Elektronik Mühendisliği \\ Bölümü, Nevşehir, TÜRKIYY \\ gokselgokkus@nevsehir.edu.tr
}

(Geliş/Received: 12.07.2021; Kabul/Accepted in Revised Form: 04.08.2021)

\begin{abstract}
In this study, research has been conducted on how to adapt the digital twin concept on wind and solar energy systems, which are alternatives to existing energy sources and have the largest share compared to other alternative energy sources. Predictions have been made on possible benefits provided to these energy sources by the digital twin concept, which is one of the popular study topics today. For this purpose, firstly, the concept of the digital twin is introduced and information about its recent applications is given. Then, information is given about how the digital twin concept can be adapted to alternative energy sources, as suggested within the scope of the study. In addition, academic studies in the field of renewable/alternative energy resources are examined and evaluations are made on the findings.
\end{abstract}

Key Words: Digital twin concept, Renewable energy sources, Industry trend

\section{Yenilenebilir Enerji Kaynakları İçin Dijital İkiz Konsepti}

ÖZ: Bu çalışmada; mevcut enerji kaynaklarına alternatif niteliğinde olan ve diğer alternatif enerji kaynaklarına oranla en büyük paya sahip rüzgar ve güneş enerji sistemleri üzerine dijital ikiz konseptinin nasıl adapte edilebileceği hakkında araştırmalar yapılmıştır. Günümüzde popüler çalışma konularından biri olan dijital ikiz konseptinin bu enerji kaynaklarına ne gibi faydalar sağlayabileceği üzerine öngörülerde bulunulmuştur. Bu amaçla öncelikli olarak dijital ikiz konsepti tanıtılmış ve günümüzdeki uygulamaları hakkında bilgiler verilmiştir. Daha sonra çalışma kapsamında önerilen şekli ile dijital ikiz konseptinin alternatif enerji kaynaklarına nasıl adapte edilebileceği hakkında bilgiler verilmiştir. Ek olarak yenilenebilir/alternatif enerji kaynakları alanında yapılan akademik çalışmalar incelenmiş ve elde edilen bulgular üzerinde değerlendirmeler yapılmıştır.

Anahtar Kelimeler: Dijital ikiz konsepti, Yenilenebilir enerji kaynakları, Endüstri trendleri

\section{INTRODUCTION}

Renewable energy sources and the power components that make up these energy sources produce errors with the effect of the environment, the user, and the loads they feed (Peng, Zhao, \& Wang, 2021). These errors can be examined under two headings, mechanical and electrical, depending on the structure of the system. The lifespan of energy systems and the sustainability of energy production can be achieved by pre-detection of the mentioned faults. It may be possible to get rid of the situation without damaging the system or with the least damage by predicting the errors and determining a strategy accordingly. Today, digitalization in industrial areas and the methods used in production 
processes allow their continued operation without interruption (Liu, Fang, Dong, \& Xu, 2021). This digitalization not only reduces the production costs of products, but also increases the production quality (Kritzinger, Karner, Traar, Henjes, \& Sihn, 2018). Rapid developments in technology fields such as artificial intelligence and 5G have paved the way for industrial Internet of Things (IIoT) applications to be included in production processes (Lu, Huang, Zhang, Maharjan, \& Zhang, 2021). With such new trends in the field of production, it has become possible to digitally monitor, optimize and control the behavior of the systems, and to produce digital copies of the data obtained (Lattanzi, Raffaeli, Peruzzini, \& Pellicciari, 2021). With the contribution of industry 4.0, which is seen as another development branch in the industry, many concepts have come to the fore, one of these concepts is the digital twin (DT) (Juarez, Botti, \& Giret, 2021). The digital twin also enables sub-developments such as automatic error checking with the support of the advantages of industry 4.0 and the new trends in the digitalization of the industry such as the internet of things (Sun, Lei, Wang, Liu, \& Zhang, 2021), (Arafet \& Berlanga, 2021). Sub-developments such as error control are developments that are used extensively especially in power generation facilities. By adding various deep learning methods to these developments, the area of influence has been expanded. The contribution of highly digitized production technologies such as Additive Manufacturing (AM) increases the capability of the digital twin concept (Bartsch, Pettke, Hubert, Lakamper, \& Lange, 2021). The digital twin concept is used extensively in the field of aviation, apart from being used in multi-unit production. As an example of its use in this field, it can also be used in the production processes of aircraft, in the realization of complex designs, and in solving the limitations caused by human, environmental, design, and production errors (Cai, Zhu, \& Zhang, 2021). The digital twin concept is not only used in energy production but also helps to consume energy efficiently and consciously and to reduce environmental pollution. 18\% of carbon dioxide formation worldwide is produced by vehicles operating in the field of transportation (Bhatti, Mohan, \& Singh, 2021). One of the two most important components affecting the development of machine learning, which is one of the popular fields of study today, is big data and the other is the digital twin (An, Chua, \& Mironov, 2021). Various academic studies have proven that especially the use of electric vehicles and the digital twin concept that will be included in the management of these vehicles can contribute positively to reducing carbon dioxide emissions. In addition to all these, the digital twin concept can be used to predict the future performance, behavior, maintenance and repair needs of complex distributed energy systems (Rassolkin et al., 2021).

\section{MATERIAL AND METHOD}

In this section, the definition of the digital twin concept is given through the academic studies observed in the literature review, and information about the adaptation of this concept to wind and solar energy systems is given. The term digital twin was first introduced by Grievens during a presentation he made in 2003 (Lim, Zheng, \& Chen, 2020), (Sjarov et al., 2020). As a digital twin definition; it is a digital structure created to understand, model, and improve the performance of the physical system. In other words, it is a virtual representation of a physical system (Schroeder et al., 2021). According to Grievens, the ability of a system to have a digital twin depends on three components. The first of these; a physically existing system to be digitally twinned, secondly; a digital copy of the system that allows to observe the behavior of the system one-to-one or to observe the changes, and thirdly; the data that will connect the physically existing system and its digital copy.

The data used in the digital twin concept are not retrospective heaps of data but are created or obtained from parameters that change in real-time. It is the visualization of multi-point or multi-source, synchronous data received over the real system with the concept of the digital twin, in a way to show the status of the real system. These data include electrical, mechanical, and environmental data that may affect the operation of the system. In addition, these data vary depending on time, temperature, vibration, pressure, torsion, etc. parameters as well as video and photo, which are editable images. The sources from which the data is provided; a wide variety of sensor structures, transducers, camera 
(thermal, IR, etc.), unmanned aerial vehicles (drone/UAV), etc. possible to sort. All these data can be visualized in $3 \mathrm{D}$ or $4 \mathrm{D}$ to create a digital copy of the system. The block diagram of the digital twin concept is given in Figure 1.

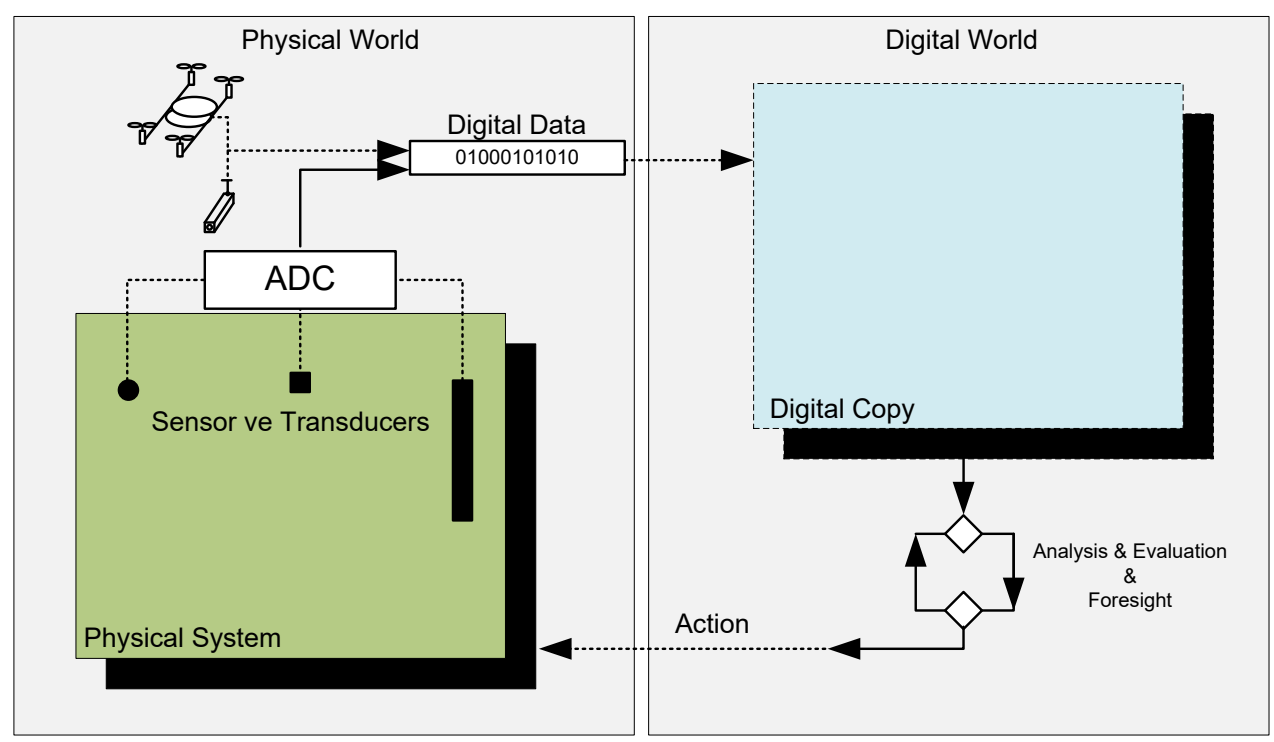

Figure 1. Block diagram of the digital twin concept

The dynamics of the systems play an important role in the implementation of the digital twin concept, but if it is desired to generalize, the digital twin concept can be created by fulfilling the following processes and stages. These processes and stages that can be applied to many systems or processes can be divided into sub-branches and detailed. The components of the created digital twin concept are adapted to the platforms that generate electricity from wind and solar energy.

Physical system: It is the physical component of the system. This component can be a building, energy platform, or mobile system.

Sensors and transducers: Various analog signals originating from the system or environment that affect the operation of the energy system in the physical structure; Electronic components of various structures to be used in sensing various mechanical parameters such as vibration, temperature, rotational speeds on shafts, pollution on panels, low-high pressure and electrical parameters such as current, voltage, power provided by the energy system.

Numerical data: It is the information obtained by converting analog signals detected by sensors and transducers into digital data. The continuity of the digital copy process can be ensured by obtaining this information securely and regularly.

Digital twin: The data received from the physical system is a digital copy of the system created in the province.

Analysis and evaluation: It is a set of processes created for the evaluation of the information obtained through the sensors and the analysis with various optimization and algorithms.

Foresight and action: The results obtained from the analysis and evaluation process turn into action in the process of foresight and action. Situations learned or predicted from the past that may prevent the operation of the system are decided in this section and precautions are taken.

If we list a few of the advantages that will arise with the adaptation of the digital twin concept to energy systems;

- Risk reduction can be made while transitioning from design to operation.

- Using the virtual model for digital modernization and maintenance can be beneficial.

- By using (Internet of Things, IOT) sensors, unmanned aerial vehicles, and other data sources, asset performance/asset management can be done and efficient system investments can be provided. 
- Structural and mechanical integrity management can be provided to reduce maintenance costs and extend the life of the energy system.

- System analysis can be done in a shorter time with high-performance calculation.

- It can enable automatic and uninterrupted system design and management.

The components needed when we want to create a digital twin of the physical system are:

- 4D design (4D Design)

- Simulation

- It is possible to list it as optimized scheduling.

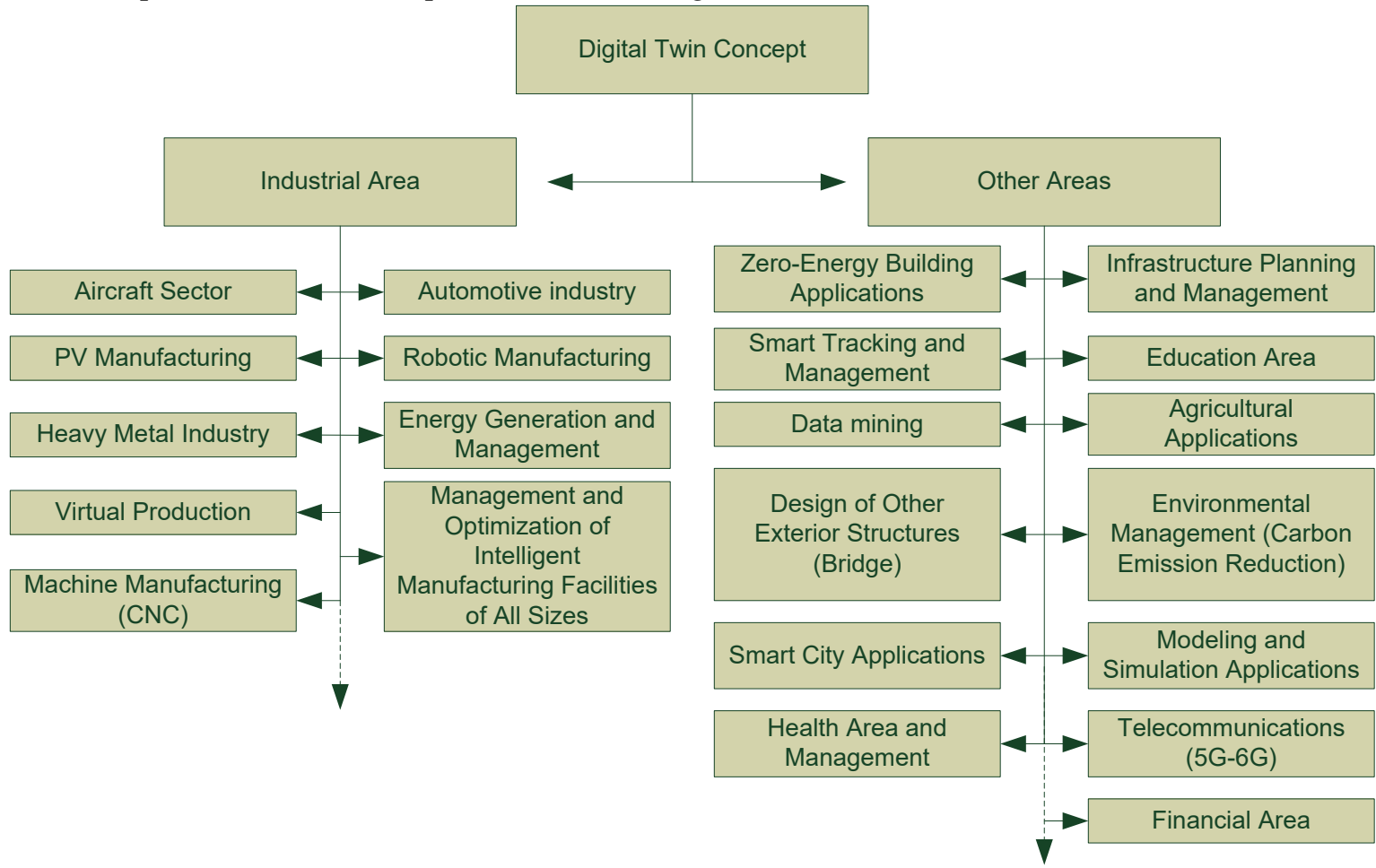

Figure 2. Diagram of the fields in which the digital twin concept is applied

A classification of the areas where the digital twin concept is applied, encountered in the literature review conducted within the scope of this study, has been made and given as a diagram in Figure 2. According to this diagram, it is seen that the most intense area where the digital twin concept is applied is the industrial area, as it is a developing trend with the support of industry 4.0 and IoT, but it is also used intensively in other areas. It is supported by academic studies, which include energy production and management, among the areas where the digital twin concept is applied. The use of these sources, known as distributed renewable energy resources (DRESs), which are alternatives to existing energy sources, which are mostly based on fossil fuels, contribute to the reduction of greenhouse gas and carbon dioxide production. However, the integration of these resources into the existing system and the inability to fully control and manage them may cause certain problems (Nguyen, Tran, Besanger, Jung, \& Nguyen, 2021). Real-time monitoring of such energy sources with the DT concept helps to eliminate many problems that energy service institutions and organizations will encounter in the field (DarbaliZamora et al., 2021).

\subsection{Digital Twin Concept on Wind Energy Systems}

Energy use and the need for energy are increasing all over the world. Wind energy promises to meet this need to a large extent and clean energy. The most widespread application area in the field of wind 
energy is the ocean or offshore wind turbines (OWTs) platforms (Wang et al., 2021). Whether terrestrial or offshore, the digital twin concept is applicable and beneficial for wind turbines of all types.

Especially for off-shore platforms, whether fixed or floating, the digital twin concept plays an important role in protecting and monitoring these platforms against ship traffic, load density, corrosion, and glacial effects. In addition, the turbine tower, which is one of the components that make up the wind turbines in the fixed platform structure, greatly contributes to the seabed and installation situation. For wind turbines with floating platform structures, static fixation provides benefits in terms of load and motion connection. The rotor, bearings, gearbox, generator, and power converters that make up the wind turbines constitute $57 \%$ of the total faults. The recovery time of these faults also constitutes $65 \%$ of the total downtime of the turbine. Due to costly and slow-paced offshore operations, the costs of troubleshooting wind turbines in the form of floating platforms are expected to be higher (Moghadam, Reboucas, \& Nejad, 2021). Figure 3 shows the external factors affecting the wind turbines in the floating platform structure.

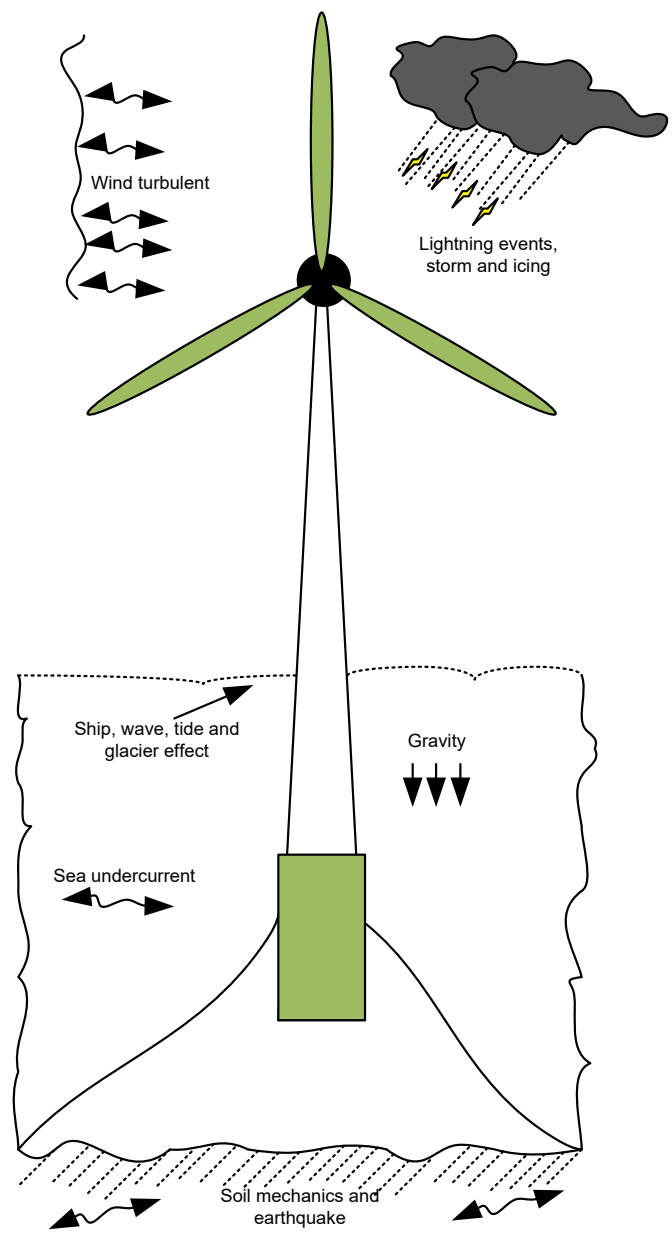

Figure 3. The external factors affecting the wind turbines in the floating platform structure

Wind turbines should have a long life due to their investment costs and structures and should be able to continue to provide energy for nearly 20 years with high reliability (Wang et al., 2021). With the digital twin concept applied to turbines, it becomes more possible to achieve these goals. As a result of the observations obtained from the literature, a model example of the application of the digital twin concept to a wind turbine is given in Figure 4. As a result of the various forces that the turbines are exposed to while generating electricity from the wind, the tower, blades, etc., which are the support structures of the turbines. Since components are prone to damage, the diagnosis of the malfunction that may occur in this case can be determined by the digital twin concept to estimate the remaining useful life of the turbine components. In the event of such failure, it is essential to strengthening structural reliability to 
prevent unexpected failures and reduce operating costs by performing appropriate maintenance processes. By real-time monitoring of the operating state of the support structures of a wind turbine, regardless of its construction or application technique, it is possible with the digital twin concept to detect initial structural cracks and assess potential risks. As a result, turbine downtime and maintenance costs can be significantly reduced and the wind turbine service life extended.
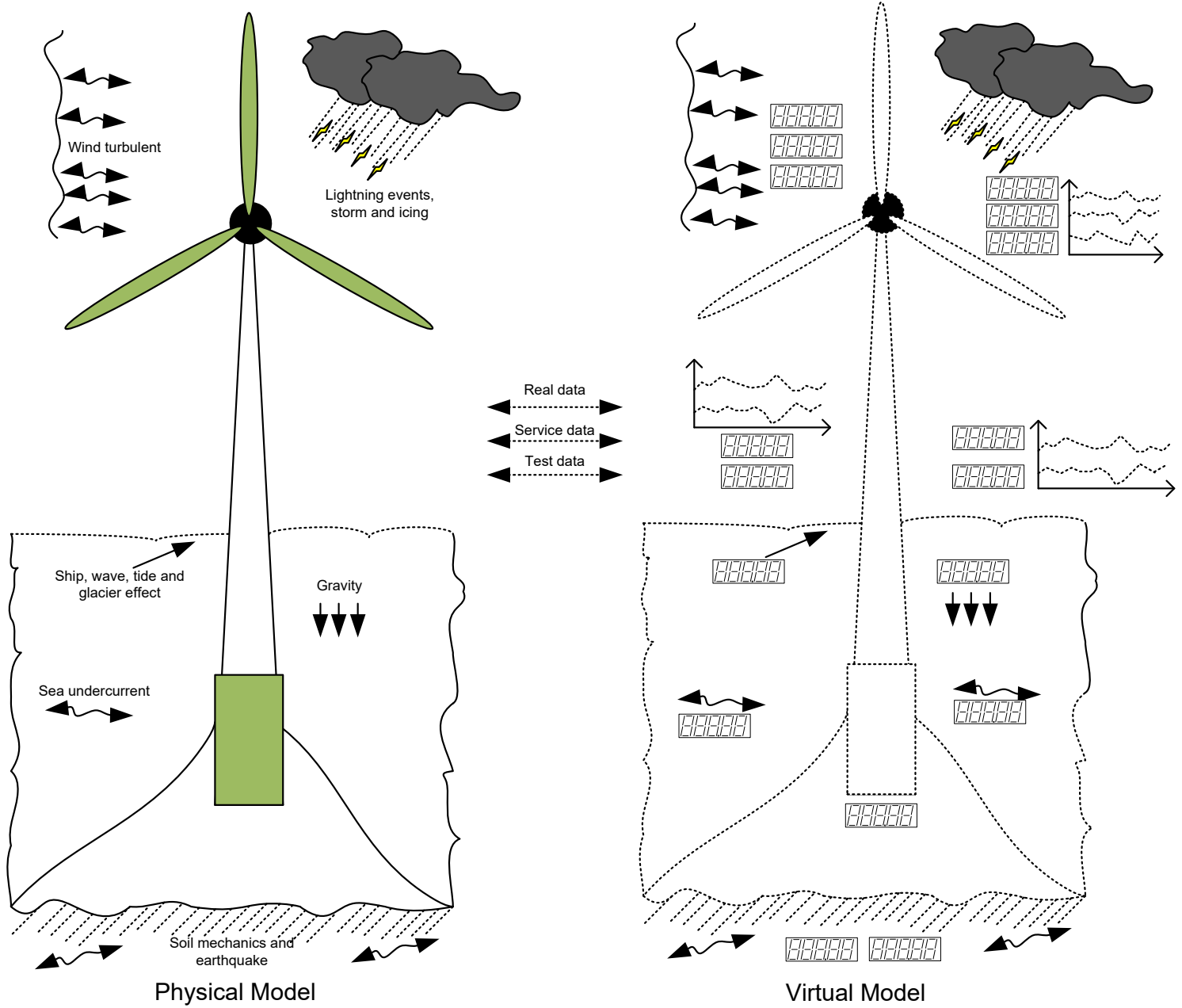

Figure 4. Example of digital twin model of offshore wind turbine application

In addition, the digital twin concept provides information about future investments and guides investors about the suitability of the system to be established for the region (Oksel, 2016). With the optimization techniques to be added to the concept structure, it can be ensured that such systems with high investment costs can make a profit by meeting the investment costs in the shortest time and shorten the payback period.

\subsection{Digital Twin Concept on Solar Energy Systems}

Solar energy is more interesting than other alternative energy sources in meeting the electricity needs of residential or commercial buildings (Uzum, Onen, Hasanien, \& Muyeen, 2021). Digital twin applications can also be made for energy systems that include photovoltaic (PV) panels, which is one of the techniques used in electricity generation from solar energy. In this context, the digital twin concept (Zohdi, 2021) is used to monitor and optimize the energy flow of complex and multi-purpose solar energy systems called Agrophotovoltaic (APV). In addition, real-time condition forecasting and detection using the digital twin concept can be used to optimize energy and grid services provided by distributed energy sources. Hot spots that occur in energy conversion systems where PV panels are 
used, causing a PV cell or group of cells to heat up significantly and fail to generate power, are one of the major problems. Hot spots affect the performance of PV modules, causing losses. Moreover, the hot spots cause the cells to deteriorate and the PV system to lose its reliability (Dhimish, 2021). For PV energy systems with central inverter, string inverter, multi-array or micro-inverter architectures with lower cost, longer life and compact size, dq, alpha beta, abc, faulty transition and combined used in balanced and unbalanced grid integration (Kolantla, Mikkili, Pendem, \& Desai, 2020) It may also be possible to develop different control strategies such as power flow control with the digital twin concept. It plays an important role in eliminating the measurement deficiency in the transmission and distribution area of electrical energy. Optimal reactive power control of distributed energy sources can also be used to reduce voltage violations caused by the inputs of PV systems into the existing system (Darbali-Zamora et al., 2021). Roof-mounted, building-integrated, or outdoor-applied solar energy systems play an important role in the application of smart technologies (Jain et al., 2020). In addition, with the application of the digital twin concept to PV systems, the data obtained from these systems can provide reference information for new systems to be established, as well as important information to investors who want to invest in this field (Cetinkaya, 2017). In Figure 5, a sample digital twin concept block diagram for the solar energy system using PV panels as a source is given.

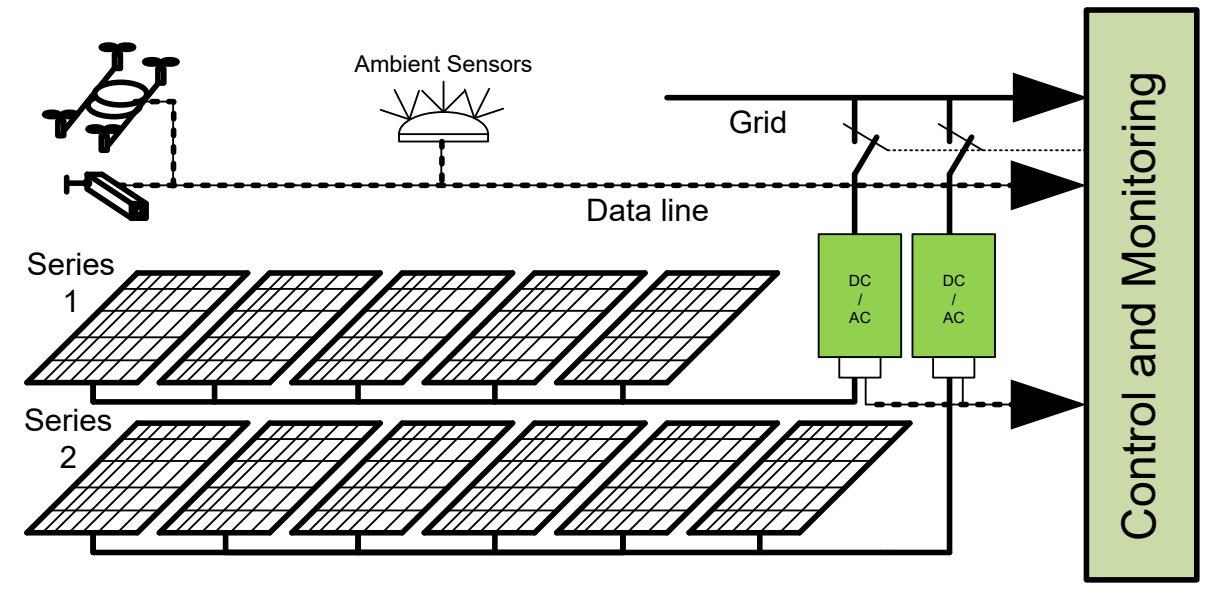

Figure 5. Example of digital twin concept for PV systems

\section{RESULTS AND DISCUSSION}

In the study; a literature review was conducted on the adaptation of the digital twin concept, which is popular in many fields today, to wind and solar energy resources, supported by digitalization studies such as industry 4.0 and the Internet of Things (IoT).

As a result of the examination, it has been seen that the digital twin concept is used most intensively in the industrial field and as sub-fields;

- Monitoring and control of production processes,

- Design and simulation of aircraft,

- It is possible to list areas such as monitoring, error inspection, and control of systems that are inaccessible or such as offshore energy platforms. In real-time monitoring; By looking at the environmental and mechanical parameters besides the electrical parameters of the system, information about the state of the energy system is obtained from the data obtained, and it is possible to detect possible fault situations in advance.

Digital twin applications are included to examine the effects of various internal and external effects on the system, such as air, water pressure, and the forces created by this pressure, affecting energy systems. Observing the effects of dusting and pollution, which affects the performance of energy conversion systems widely preferred in electricity generation from solar energy in which solar panels are used, is possible with the digital twin. In addition, it is possible to detect the situation (hot spot) that 
occurs in solar energy systems where a large number of panels in the array inverter structure are used and causes the panels to overheat locally, with thermal or IR cameras in the digital twin concept. As a result of this determination, it is ensured that the panels serve for longer periods without being damaged and that the energy system can produce energy uninterruptedly. According to the academic studies examined; Many data sources such as sensors, transducers, cameras, unmanned aerial vehicles can be used to create the digital twin concept. The fact that this data is real-time is also important in terms of the applicability of the digital twin concept. However, there is also the use of non-real-time data. These data can be data such as historical maintenance and service data. Since the physical system in the definition of the digital twin concept is a digital twin, it needs visualization technologies such as 3D/4D. In addition to all these, it is possible to develop the digital twin concept's ability to make predictions using data and make quick decisions with various algorithms and optimization techniques. In terms of all these usage areas and advantages, using the digital twin concept in smart and living cities and smart grid applications will be beneficial in every sense. In addition to all these aspects, thanks to the literature review made within the scope of the study and the proposals for the digital twin concept for energy systems, it can be a guide for future academic studies.

\section{REFERENCES}

An, J., Chua, C. K., \& Mironov, V. (2021). "Application of Machine Learning in 3D Bioprinting: Focus on Development of Big Data and Digital Twin", International Journal of Bioprinting, 7(1), 1-6. doi: ARTN 34210.18063/ijb.v7i1.342

Arafet, K., \& Berlanga, R. (2021). "Digital Twins in Solar Farms: An Approach through Time Series and Deep Learning", Algorithms, 14(5). doi: ARTN 15610.3390/a14050156

Bartsch, K., Pettke, A., Hubert, A., Lakamper, J., \& Lange, F. (2021). "On the digital twin application and the role of artificial intelligence in additive manufacturing: a systematic review", Journal of Physics-Materials, 4(3). doi: ARTN 03200510.1088/2515-7639/abf3cf

Bhatti, G., Mohan, H., \& Singh, R. R. (2021). "Towards the future of smart electric vehicles: Digital twin technology", Renewable \& Sustainable Energy Reviews, 141. doi:ARTN 11080110.1016/j.rser.2021.110801

Cai, H. X., Zhu, J. M., \& Zhang, W. (2021). "Quality Deviation Control for Aircraft Using Digital Twin", Journal of Computing and Information Science in Engineering, 21(3). doi:Artn031008

Çetinkaya, N. (2017). "Improving of renewable energy support policy and a performance analysis of a grid-connected 1 MWP PV power plant in Konya", Selçuk Üniversitesi Mühendislik, Bilim ve Teknoloji Dergisi, 5(3), 251-261.10.1115/1.4050376

Darbali-Zamora, R., Johnson, J., Summers, A., Jones, C. B., Hansen, C., \& Showalter, C. (2021). "State Estimation-Based Distributed Energy Resource Optimization for Distribution Voltage Regulation in Telemetry-Sparse Environments Using a Real-Time Digital Twin", Energies, 14(3). doi: ARTN 77410.3390/en14030774

Dhimish, M. (2021). "Defining the best-fit machine learning classifier to early diagnose photovoltaic solar cells hot-spots", Case Studies in Thermal Engineering, 25. doi: ARTN 10098010.1016/j.csite.2021.100980

Jain, P., Poon, J., Singh, J. P., Spanos, C., Sanders, S. R., \& Panda, S. K. (2020). "A Digital Twin Approach for Fault Diagnosis in Distributed Photovoltaic Systems", Ieee Transactions on Power Electronics, 35(1), 940-956. doi: 10.1109/Tpel.2019.2911594

Juarez, M. G., Botti, V. J., \& Giret, A. S. (2021). "Digital Twins: Review and Challenges", Journal of Computing and Information Science in Engineering, 21(3). doi: Artn 03080210.1115/1.4050244

Kolantla, D., Mikkili, S., Pendem, S. R., \& Desai, A. A. (2020). "Critical review on various inverter topologies for PV system architectures", Iet Renewable Power Generation, 14(17), 3418-3438. doi: 10.1049/iet-rpg.2020.0317 
Kritzinger, W., Karner, M., Traar, G., Henjes, J., \& Sihn, W. (2018). "Digital Twin in manufacturing: A categorical literature review and classification", Ifac Papersonline, 51(11), 1016-1022. doi: 10.1016/j.ifacol.2018.08.474

Lattanzi, L., Raffaeli, R., Peruzzini, M., \& Pellicciari, M. (2021). "Digital twin for smart manufacturing: a review of concepts towards a practical industrial implementation", International Journal of Computer Integrated Manufacturing. doi: 10.1080/0951192x.2021.1911003

Lim, K. Y. H., Zheng, P., \& Chen, C. H. (2020). "A state-of-the-art survey of Digital Twin: techniques, engineering product lifecycle management and business innovation perspectives", Journal of Intelligent Manufacturing, 31(6), 1313-1337. doi: 10.1007/s10845-019-01512-w

Liu, M. N., Fang, S. L., Dong, H. Y., \& Xu, C. Z. (2021). "Review of digital twin about concepts, technologies, and industrial applications", Journal of Manufacturing Systems, 58, 346-361. doi: 10.1016/j.jmsy.2020.06.017

Lu, Y. L., Huang, X. H., Zhang, K., Maharjan, S., \& Zhang, Y. (2021). "Communication-Efficient Federated Learning for Digital Twin Edge Networks in Industrial IoT", Ieee Transactions on Industrial Informatics, 17(8), 5709-5718. doi: 10.1109/Tii.2020.3010798

Moghadam, F. K., Reboucas, G. F. D., \& Nejad, A. R. (2021). "Digital twin modeling for predictive maintenance of gearboxes in floating offshore wind turbine drivetrains", Forschung Im Ingenieurwesen-Engineering Research, 85(2), 273-286. doi: 10.1007/s10010-021-00468-9

Nguyen, V. H., Tran, Q. T., Besanger, Y., Jung, M., \& Nguyen, T. L. (2021). "Digital twin integrated power-hardware-in-the-loop for the assessment of distributed renewable energy resources", Electrical Engineering. doi: 10.1007/s00202-021-01246-0

ÖKSEL, C., Ali, K. O. Ç., Yıldız, K. O. Ç., \& YAĞLI, H. (2016). "Off-shore Wind Energy Potential Research for Antakya Bay", Selçuk Üniversitesi Mühendislik, Bilim ve Teknoloji Dergisi, 4(1), 18-29.

Peng, Y. Z., Zhao, S., \& Wang, H. (2021). "A Digital Twin Based Estimation Method for Health Indicators of DC-DC Converters", Ieee Transactions on Power Electronics, 36(2), 2105-2118. doi: 10.1109/Tpel.2020.3009600

Rassolkin, A., Orosz, T., Demidova, G. L., Kuts, V., Rjabtsikov, V., Vaimann, T., \& Kallaste, A. (2021). "Implementation of Digital Twins for electrical energy conversion systems in selected case studies", Proceedings of the Estonian Academy of Sciences, 70(1), 19-39. doi: 10.3176/proc.2021.1.03

Schroeder, G. N., Steinmetz, C., Rodrigues, R. N., Henriques, R. V. B., Rettberg, A., \& Pereira, C. E. (2021). "A Methodology for Digital Twin Modeling and Deployment for Industry 4.0", Proceedings of the Ieee, 109(4), 556-567. doi: 10.1109/Jproc.2020.3032444

Sjarov, M., Lechler, T., Fuchs, J., Brossog, M., Selmaier, A., Faltus, F., Franke, J. (2020). "The Digital Twin Concept in Industry - A Review and Systematization", 2020 25th Ieee International Conference on Emerging Technologies and Factory Automation (Etfa), 1789-1796.

Sun, W., Lei, S. Y., Wang, L., Liu, Z. Q., \& Zhang, Y. (2021). "Adaptive Federated Learning and Digital Twin for Industrial Internet of Things", Ieee Transactions on Industrial Informatics, 17(8), 56055614. doi: 10.1109/Tii.2020.3034674

Uzum, B., Onen, A., Hasanien, H. M., \& Muyeen, S. M. (2021). "Rooftop Solar PV Penetration Impacts on Distribution Network and Further Growth Factors-A Comprehensive Review", Electronics, 10(1). doi: ARTN 5510.3390/electronics10010055

Wang, M. M., Wang, C. Y., Hnydiuk-Stefan, A., Feng, S. Z., Atilla, I., \& Li, Z. (2021). "Recent progress on reliability analysis of offshore wind turbine support structures considering digital twin solutions.", Ocean Engineering, 232. doi: ARTN 10916810.1016/j.oceaneng.2021.109168

Zohdi, T. I. (2021). "A digital-twin and machine-learning framework for the design of multiobjective agrophotovoltaic solar farms.", Computational Mechanics. doi:10.1007/s00466-021-02035-z 